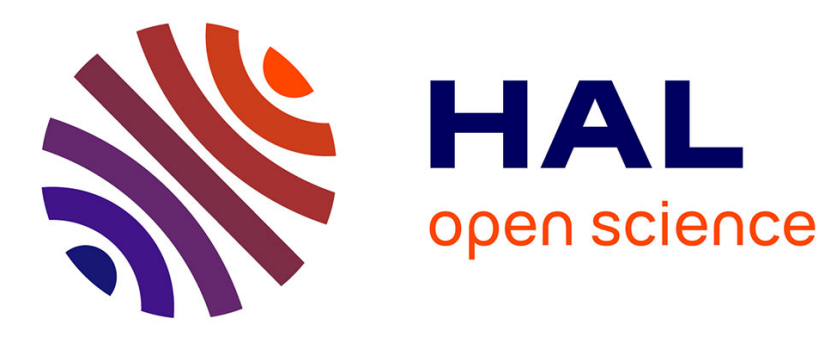

\title{
Is the early-onset torsion dystonia (EOTD) linked to TOR1A gene as frequent as expected in France?
} Mélissa Yana Frédéric, Fabienne Clot, Laura Cif, Arnaud Blanchard, Alexandra Dürr, Isabelle Vuillaume, Gaetan Lesca, Alexandre Kreisler, Caroline Davin, Thomas Besnard, et al.

\section{To cite this version:}

Mélissa Yana Frédéric, Fabienne Clot, Laura Cif, Arnaud Blanchard, Alexandra Dürr, et al.. Is the early-onset torsion dystonia (EOTD) linked to TOR1A gene as frequent as expected in France? neurogenetics, 2008, 9 (2), pp.143-50. 10.1007/s10048-008-0123-7 . inserm-00343965

\section{HAL Id: inserm-00343965 https://www.hal.inserm.fr/inserm-00343965}

Submitted on 20 Dec 2017

HAL is a multi-disciplinary open access archive for the deposit and dissemination of scientific research documents, whether they are published or not. The documents may come from teaching and research institutions in France or abroad, or from public or private research centers.
L'archive ouverte pluridisciplinaire HAL, est destinée au dépôt et à la diffusion de documents scientifiques de niveau recherche, publiés ou non, émanant des établissements d'enseignement et de recherche français ou étrangers, des laboratoires publics ou privés. 


\title{
Is the early-onset torsion dystonia (EOTD) linked to TOR $1 A$ gene as frequent as expected in France?
}

\author{
M. Y. Frédéric • F. Clot • L. Cif • A. Blanchard • \\ A. Dürr • I. Vuillaume • G. Lesca • A. Kreisler • \\ C. Davin • T. Besnard $\cdot$ F. Rousset $\cdot$ D. Thorel $\cdot$ \\ C. Saquet • D. Mechin $\cdot$ L. Ozelius $\cdot$ Y. Agid • \\ B. Barroso - B. Chabrol • V. Chan • M. Clanet • \\ C. Coubes $\cdot$ A. Destee $\cdot$ K. Nguyen $\cdot$ C. Vial .
}

M. Vidailhet • J. Xie • B. Sablonniere $\cdot$ A. Calender •

A. Brice • A. Roubertie $\cdot$ P. Coubes $\cdot$ M. Claustres •

S. Tuffery-Giraud $\cdot$ G. Collod-Beroud

\begin{abstract}
Early onset torsion dystonia are rare movement disorders. Molecular defect is known for only a subgroup, consisting of a unique and recurrent mutation in the TOR $1 A$ gene. We undertook a nationwide census of French TOR1A-
\end{abstract}

M. Y. Frédéric $\cdot$ A. Blanchard · C. Davin · T. Besnard

F. Rousset $\cdot$ M. Claustres $\cdot$ S. Tuffery-Giraud $\cdot$ G. Collod-Beroud INSERM, U827,

Montpellier F-34000, France

M. Y. Frédéric · A. Blanchard • C. Davin · T. Besnard •

F. Rousset $\cdot$ M. Claustres $\cdot$ S. Tuffery-Giraud $\cdot$ G. Collod-Beroud Université MONTPELLIER1, UFR Médecine,

Montpellier F-34000, France

F. Clot $\cdot$ A. Dürr $\cdot$ Y. Agid $\cdot$ M. Vidailhet $\cdot$ A. Brice

INSERM, UMR_S679 Neurologie \& Thérapeutique Expérimentale,

Paris F-75013, France

F. Clot $\cdot$ A. Dürr $\cdot$ Y. Agid $\cdot$ M. Vidailhet $\cdot$ A. Brice

UPMC Univ Paris 06, UMR S679,

Paris F-75005, France

F. Clot $\cdot$ A. Dürr $\cdot$ Y. Agid $\cdot$ M. Vidailhet $\cdot$ A. Brice $\cdot$ P. Coubes Institut Fédératif des Neurosciences (IFR70),

Hôpital Pitié-Salpêtrière,

Paris F-75013, France

F. Clot · A. Dürr · A. Brice

AP-HP, Hôpital Pitié-Salpêtrière,

Département de Génétique et Cytogénétique,

Paris F-75013, France mutation carriers and the assessment of clinical associated signs. Overall, 53 index cases and 104 relatives were studied and haplotypes linked to the mutation constructed. The previously reported Ashkenazi-Jewish haplotype was

L. Cif

CHU Montpellier, Hôpital Guy de Chauliac,

Service de Neurochirurgie,

Montpellier F-34000, France

I. Vuillaume $\cdot$ B. Sablonniere

CHRU de Lille, UF de Neurobiologie,

Centre de Biologie-Pathologie,

Lille F-59037, France

B. Sablonniere

INSERM, U837,

Institut de Médecine prédictive et de recherche thérapeutique,

Lille F-59045, France

G. Lesca $\cdot$ A. Calender

Hôpital Edouard Herriot,

service de Génétique Moléculaire et Clinique,

Lyon F-69437, France

G. Lesca $\cdot$ A. Calender

Université Claude Bernard Lyon1,

Villeurbanne F-69622, France

\section{A. Kreisler $\cdot$ A. Destee}

Service de Neurologie et pathologie du mouvement (EA2683),

Département neurosciences de l'IFR 114 IMPRT,

CHU de Lille F-59037, France 
found in 11 families with the remainder carrying distinct haplotypes suggesting independent mutation events. This study demonstrates the scarcity of this disease in France with estimated disease frequency of $0.13: 100,000$ and mutation frequency of 0.17:100,000.

Keywords Early onset torsion dystonia (EOTD) - DYT1 . TOR1A P Population study

\section{Introduction}

Primary dystonia are rare disorders caused by involuntary twisting and repetitive movements, or abnormal postures in the absence of other neurological symptoms or secondary causes. In "typical" idiopathic early onset torsion dystonia (EOTD), symptoms develop first in the arm or leg in middle to late childhood and frequently progress to generalized dystonia within about 5 years $[1,2]$. Currently, the only identified gene for EOTD is the TOR1A gene that encodes the torsinA protein [3]. The majority of cases from various ethnic groups are caused by a unique and recurrent autosomal dominantly inherited deletion of $3 \mathrm{bp}$ (c.907delGAG) in exon 5 of this gene $[1,3,4]$. Low penetrance $(30 \%)$ is reported regardless of ethnic origin [5-7]. In expressing individuals, there is a strong clinical variability, ranging from children profoundly handicapped to obligate carriers of the disease gene showing only a few signs of the disorder [8-10]. TOR1A mutations are estimated to account for about $30-60 \%$ of early onset dystonia in non-Jews and about $80-90 \%$ in Ashkenazi-Jews (AJ) due to a founder effect [11]. In other populations, the presence of TOR1Alinked haplotypes different from the AJ and from each other [12] argues for the occurrence of multiple independent events that have given rise to the deletion $[1,13]$ even though some studies identified a restricted number of distinct haplotypes [14-16].

Previous epidemiological surveys associated with screening of the mutation have allowed estimation of the prevalence of TOR1A-linked dystonia among non-Jews to about $1 / 10,000$ to $1 / 30,000$ [17]. In a previous study, we investigated the incidence at birth of the c.907delGAG

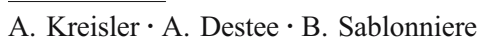

Université de Lille 2 Droit et Santé, UFR Médecine,

Lille F-59045, France

D. Thorel $\cdot$ C. Saquet $\cdot$ D. Mechin $\cdot$ M. Claustres

CHU Montpellier, Hôpital Arnaud de Villeneuve,

Laboratoire de Génétique Moléculaire,

Montpellier F-34000, France

L. Ozelius

Department of Genetics and Genome Sciences,

Mount Sinai School of Medicine,

New York, NY, USA

Y. Agid $\cdot$ M. Vidailhet $\cdot$ A. Brice

AP-HP, Hôpital Pitié-Salpêtrière,

Fédération des Maladies du Système Nerveux,

Paris F-75013, France

B. Barroso

CHU de Pau, Service de Neurologie,

Pau F-64046, France

B. Chabrol

CHU de Marseille, Service de Neuropédiatrie,

MarseilleF-13385, France

V. Chan

CH de Valence, Service de Neurologie,

Valence F-26000, France

M. Clanet

CHU de Toulouse, Hôpital Purpan, Service de Neurologie générale et Maladies inflammatoires du système nerveux,

Toulouse F-31059, France

\author{
C. Coubes \\ CHU Montpellier, Hôpital Arnaud de Villeneuve, \\ Sercice Génétique Clinique, \\ Montpellier F-34000, France \\ K. Nguyen \\ CHU de Marseille, \\ Service de Génétique Médicale, \\ Marseille F-13385, France \\ C. Vial \\ Hospices Civils de Lyon, \\ Hôpital Neurologique et Neurochirurgical Pierre Wertheimer, \\ Service d'Electroneuromyographie et Pathologies Neuromusculaires, \\ Lyon F-69394, France \\ J. Xie \\ Hospices Civils de Lyon, \\ Hôpital Neurologique et Neurochirurgical Pierre Wertheimer, \\ Service de Neurologie C, \\ Lyon F-69394, France \\ A. Roubertie \\ CHU Montpellier, Hôpital Guy de Chauliac, \\ Service de Neuropédiatrie, \\ Montpellier F-34000, France \\ G. Collod-Beroud $(\bowtie)$ \\ INSERM U827, Institut Universitaire de Recherche Clinique, \\ 641 av du doyen Gaston Giraud, \\ 34093 Montpellier Cedex 05, France \\ e-mail: g.collod-beroud@montp.inserm.fr
}


mutation in a population of 12,000 newborns from Southeastern France. Whereas we expected between one and four positive carriers of the mutation, only one positive was found suggesting that the prevalence of the disease would be situated in the lowest values $(1 / 30,000)$ in France [18]. This observation is in accordance with the latest estimation in the general population of Europe of 0.3 to 0.5:100,000 [19].

The healthcare system organization in France, with the clear identification of referent laboratories for the molecular diagnosis of rare diseases, gives us the opportunity to identify the four laboratories involved in the detection of the TORIA mutation in Lille, Lyon, Paris and Montpellier. Collaborations were set up to collect DNA samples and clinical data on symptomatic or asymptomatic mutation carriers. The purpose of this study was threefold: (1) to evaluate the number of families and individuals carrying the c.907delGAG deletion in the TOR1A gene in France, (2) to characterize the associated French TOR1A haplotypes, and (3) to estimate the mutation penetrance from identified symptomatic and asymptomatic mutation carriers.

\section{Materials and methods}

\section{Patients and controls}

The majority of the patients included in this study are currently under follow-up or had been previously examined by a neurologist trained in analysis of movement disorders. Blood was sampled with informed consent. Physicians were contacted to examine the available clinical notes at last follow-up. Available clinical data for each symptomatic relative of a TOR1A mutation carrier were also collected. Whenever possible, the presence of the deletion was investigated in each parent. Careful examination was performed to characterize mild symptomatic dystonia. Ninety French unrelated individuals from all over the country were used as the control population to characterize allele frequencies for each marker.

\section{Molecular analysis}

The c.907delGAG mutation was assayed, or confirmed, by polymerase chain reaction followed by electrophoresis on a ABI3130XL and then by DHPLC as previously described [18]. Five polymorphic microsatellites surrounding the TOR1A locus were studied (Fig. 1) by using oligonucleotide primer pairs previously described [20]. Products were analyzed on an ABI3130XL sequencer with Genemapper software. To allow comparison of our results with those previously reported, we analyzed an Ashkenazi-Jewish DNA sample and assigned allele numbers accordingly. For each locus, the other alleles were numbered accordingly

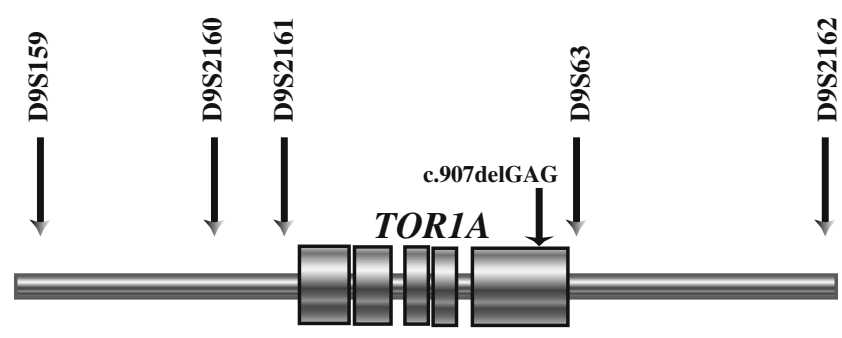
$100 \mathrm{~kb}$
$<40 \mathrm{~kb}$
$150 \mathrm{~kb}$
$130 \mathbf{k b}$

Fig. 1 Physical map of the 9q region surrounding the TOR1A gene. Position and physical distance between the five polymorphic microsatellites studied surrounding the TOR1A locus. The unique and recurrent mutation of the gene, c.907delGAG, is located in exon 5 of the gene

to their size. The control individual 1347-02 from the Centre d'Etudes du Polymorphisme Humain (CEPH) was also analyzed, and the size of observed alleles is given in Supplementary Table 1. DNA samples from the two French Canadian families [12] and from the Parisian family in which a second French AJ haplotype was previously described (PAR-11) [13] were reanalyzed for comparison of allele sizes. Marker allele frequencies were estimated by counting alleles in characterized disease-bearing chromosomes and in control individuals.

\section{Results}

Characterization of the c.907delGAG mutation-carrier population

Fifty-three index cases of EOTD carrying the c.907delGAG mutation have been identified (Supplementary Table 1). Most of the families are Caucasian and of European ancestry (PAR-05, MON-18 and MON-23 being of Polish origin). Four additional families are of Maghrebian origin (PAR-07, MON-08, MON-13, and MON-20) and one of Caribbean origin (PAR-12). AJ origins are reported in eight families: LYO-01, PAR-01, PAR-11, PAR-13, PAR-21, MON-02, MON-14, and MON-26. For 30 patients (30/53, $56.6 \%$ ), relatives with dystonia were already known. In the 23 apparently isolated cases, whenever both parents could be analyzed (five cases), a carrier was always found excluding the hypothesis of the de novo occurrence of the deletion (in 14 index cases, no samples was available for both parents, and in four cases, only one parent could be studied and excluded as carrier). After identification of the TOR1A gene mutation in the probands $(N=53)$, genetic counseling was proposed in the families, and 104 relatives were further included in the study (Fig. 2). Among the 32 affected relatives, all but two were found to carry the mutation. The first one, a relative in the MON-21 family presents with only limb motor difficulties after exercise, as 


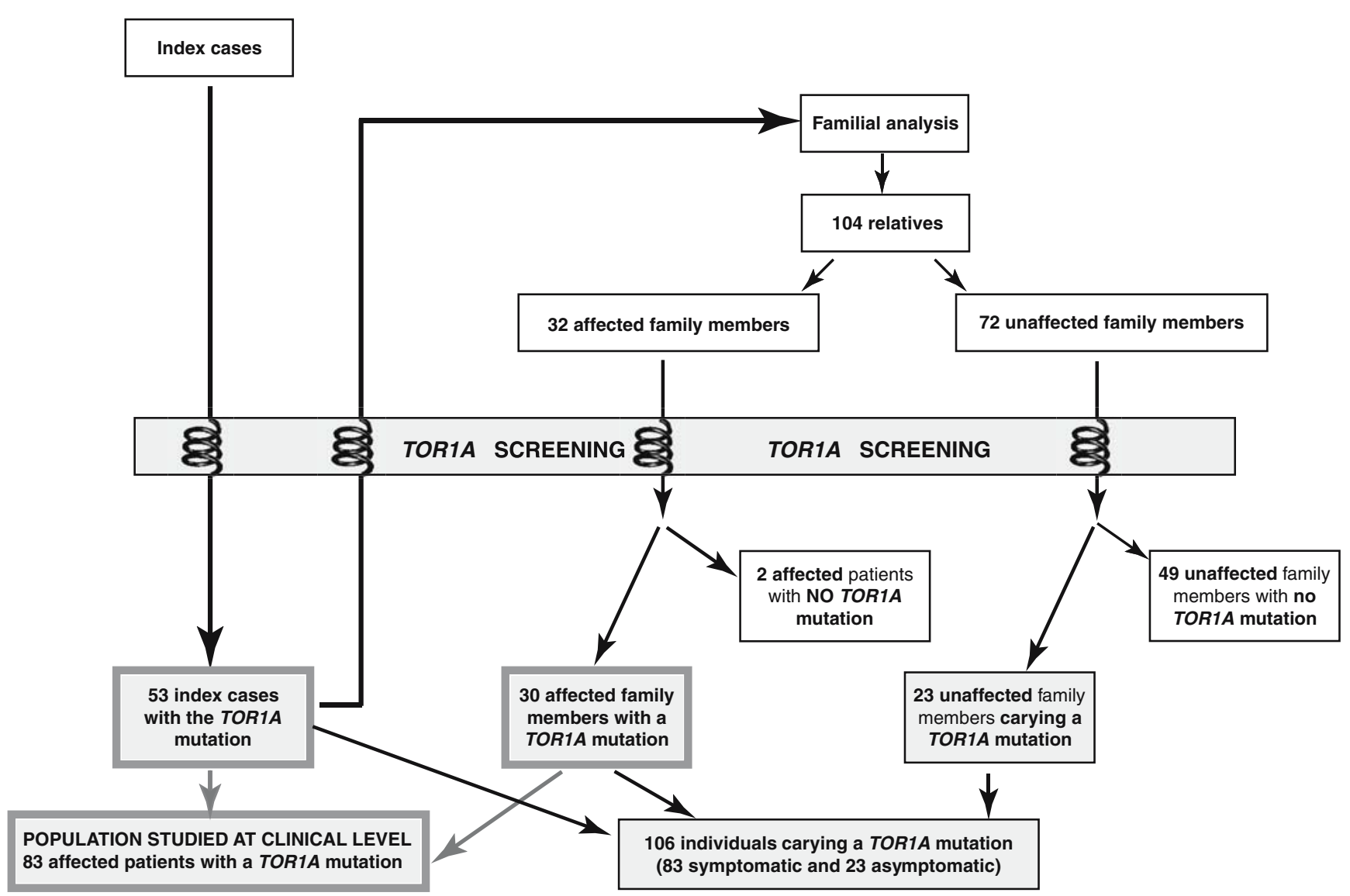

Fig. 2 Organigram summary of the study of early onset torsion dystonia (EOTD) linked to TOR1A gene in France

does his father who is a mutation carrier. The other one, a relative in the PAR-02 family, shows slight dysarthria, dystonia of both hands, the left upper limb, and the left lower limb. Among the 72 non-affected family members who were tested, 23 were found to carry the mutation, and 49 were not carriers (Fig. 2). Finally, in our French cohort, 106 individuals carry the mutation, and among them, only 23 were asymptomatic (21.7\%; Fig. 2).

\section{Clinical evaluation}

Among the 53 identified index cases, 19 underwent deep brain stimulation (10 were not operated and data are missing for 24). When studying family history of each index case, a population of 109 individuals presenting with clinical signs of dystonia was initially identified (eight were excluded from this clinical study because of incomplete clinical data, and 16 because of unknown molecular status; Fig. 2). Also, the two reported affected individuals tested negative for the TOR1A mutation (families MON-21 and PAR-02) were not included in the subsequent clinical study. Clinical characteristics of this genetically ascertained population corresponding to the 53 index cases and 30 affected relatives ( $N=83,41$ males and 42 females) are given in Table 1. A total of $91.0 \%$ had onset of symptoms in a limb (leg in $26.47 \%$ and arm in $64.7 \%$ ), while symptom onset rarely involved neck, cranial, or truncal muscles $(9.0 \%)$. The mean age at onset is 12.0 years \pm 8.2 years and ranges from 5 to 55 years, with only three cases of onset after 28 years old. The first case is a male patient developing writer's cramp at 41 years old, whereas his brother presented with generalized dystonia. The second one is an individual with generalized dystonia whose onset was at 30 years old. This woman is a member of a large dystonia family with onset ranging between 15 years and late onset. The third case is the father of an affected child. He developed writer's cramp at 55 years old, whereas his child had generalized dystonia at an early age.

The site of onset was known for 67 out of the 83 patients studied. For patients with initial leg involvement, $(N=18$, average age at onset $9.7 \pm 4$ years, average follow-up duration $20.75 \pm 18$ years $), 55.6 \%(N=10)$ show a rapid rate of progression to generalized dystonia ( 2.25 years \pm 1.2 years, maximum 5 years; Table 1). It is noteworthy that those patients tend to have an earlier age of onset $(7.8 \pm$ 1.15) than those who do not generalize $(N=8,13.6 \pm 5)$. The majority of the patients with no progression are now adults $(30.5 \pm 24$ years). Although the rate of progression is extremely variable from patient to patient, it is usually more rapid within the first 5 to 10 years after symptom 
Table 1 Comparison of French patients' clinical characteristics with different ethnic groups (population genetically ascertained c.907delGAG carriers)

\begin{tabular}{|c|c|c|c|c|c|c|}
\hline Clinical characteristics & $\begin{array}{l}\text { Asian } \\
(N=22)\end{array}$ & $\begin{array}{l}\text { American Ashkenazi- } \\
\text { Jewish }(N=45)\end{array}$ & $\begin{array}{l}\text { American non-Jewish } \\
(N=45)\end{array}$ & $\begin{array}{l}\text { French with no JA } \\
\text { haplotype }(N=64)\end{array}$ & $\begin{array}{l}\text { French with JA } \\
\text { haplotype }(\mathrm{N}=19)\end{array}$ & $\begin{array}{l}\text { French } \\
(\mathrm{N}=83)\end{array}$ \\
\hline Leg onset & $59.1 \%(13 / 22)$ & $36.5 \%$ & $60.0 \%$ & $23.08 \%$ & $40.00 \%$ & $26.47 \%$ \\
\hline Arm onset & $31.8 \%(7 / 22)$ & $59.6 \%$ & $35.5 \%$ & $65.38 \%$ & $60.00 \%$ & $64.70 \%$ \\
\hline Neck onset & $4.5 \%(1 / 22)$ & $1.9 \%$ & $4.4 \%$ & $7.69 \%$ & $0.00 \%$ & $5.88 \%$ \\
\hline Cranial onset & $0 \%$ & $1.9 \%$ & $0 \%$ & $1.92 \%$ & $0.00 \%$ & $1.47 \%$ \\
\hline truncal onset & $4.5 \%(1 / 22)$ & $0 \%$ & $0 \%$ & $1.92 \%$ & $0.00 \%$ & $1.47 \%$ \\
\hline Generalized dystonia & $54.5 \%(12 / 22)$ & $48.1 \%$ & $66.7 \%$ & $57.14 \%$ & $50.00 \%$ & $54.88 \%$ \\
\hline $\begin{array}{l}\text { Multifocal dystonia/ } \\
\text { hemi-dystonia }\end{array}$ & $9.1 \%(2 / 22)$ & $11.5 \%$ & $8.9 \%$ & $7.94 \%$ & $23.53 \%$ & $12.20 \%$ \\
\hline Segmental dystonia & $18.2 \%(4 / 22)$ & $15.4 \%$ & $8.9 \%$ & $7.94 \%$ & $17.65 \%$ & $9.76 \%$ \\
\hline Focal dystonia & $13.6 \%(3 / 22)$ & $25.0 \%$ & $15.6 \%$ & $26.98 \%$ & $11.76 \%$ & $23.17 \%$ \\
\hline Leg involvement & $72.7 \%(16 / 22)$ & $59.6 \%$ & $77.8 \%$ & $63.16 \%$ & $83.33 \%$ & $68.42 \%$ \\
\hline Arm involvement & $86.4 \%(19 / 22)$ & $96.2 \%$ & $95.6 \%$ & $85.96 \%$ & $77.78 \%$ & $84.21 \%$ \\
\hline Trunk involvement & $62.5 \%\left(10 / 16^{a}\right)$ & $26.9 \%$ & $48.8 \%$ & $47.37 \%$ & $38.89 \%$ & $44.74 \%$ \\
\hline Neck involvement & $62.5 \%\left(10 / 16^{a}\right)$ & $25.0 \%$ & $24.4 \%$ & $40.35 \%$ & $22.22 \%$ & $35.53 \%$ \\
\hline Cranial involvement & $18.8 \%\left(10 / 16^{\mathrm{a}}\right)$ & $7.7 \%$ & $11.1 \%$ & $31.58 \%$ & $27.78 \%$ & $30.26 \%$ \\
\hline Age of onset (year) & $11.5 \pm 7.5$ & \multicolumn{2}{|c|}{$14.0 \pm 9.0^{\mathrm{b}}$} & $12.3 \pm 9.2$ & $11.3 \pm 4.8$ & $12.1 \pm 8.2$ \\
\hline $\begin{array}{l}\text { Age at last } \\
\text { examination (year) }\end{array}$ & $28.1 \pm 18.3$ & \multicolumn{2}{|l|}{ - } & $32.6 \pm 17.0$ & $31.8 \pm 17.0$ & $32.2 \pm 16,8$ \\
\hline Duration & $16.6 \pm 15.6$ & \multicolumn{2}{|c|}{$25 \pm 15.7$} & $15.1 \pm 15.3$ & $18.7 \pm 16.3$ & $15.8 \pm 15.5$ \\
\hline
\end{tabular}

French: data from ours. Asian: data from Im et al. 22, Ikeuchi et al. 21, Nomura et al. 24, and Matsumoto et al. 23. Ashkenazi and non-Jewish: data from Bressman et al. 1.

${ }^{\mathrm{a}}$ Data from Matsumoto et al. 23 omitted (no comment on axial and cranial muscle involvement).

${ }^{\mathrm{b}}$ No significant difference is reported between American Ashkenazi Jewish and American non-Jewish subjects in their age-at-onset.

- Missing data

onset. Therefore, one can expect that dystonia remains localized in most of these patients.

Patients whose symptoms initially affect an arm $(N=43)$ have a later age of onset compared to the group with leg

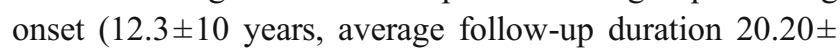
13.5 years). The dystonia progressed to a generalized form in $55.8 \%$ of patients $(N=24)$. In contrast to the group with leg onset, the rate of progression was slower (5.45 years \pm 6.5 years, maximum 21 years), and no difference in the age of onset was observed between the group with generalization $(21.9 \pm 3.75)$ and the other group $(17.9 \pm 14.24)$. Once more, in the subset of patients who do not progress to a generalized form, the majority are also now adults.

We compared the clinical characteristics of our TOR1A positive patients to those reported in the literature (Table 1). The Asian patients (Korean and Japanese, $N=22$ ) [21-24] with a TORIA mutation showed greater onset in the leg than in the arm, less focal dystonia similar to non-Jewish patients $(N=45)$, and more segmental dystonia akin to Jewish patients $(N=52)$. On the contrary, the French TORIA patients $(N=83)$ are more comparable with Jewish patients who showed more arm onset, less onset in the leg, and a higher proportion of focal dystonia.
Haplotypes linked to c.907delGAG TOR1A mutation

Five microsatellites D9S159, D9S2160, D9S2161, D9S63, and D9S2162 were studied in 157 patients and their family members (53 index cases and 104 relatives) and in 90 unrelated controls. Haplotypes were constructed in families under the assumption of minimum recombination. We were able to identify the chromosome associated with the mutation by inheritance in 28 families and the most likely associated haplotype in ten individuals (Table 2). Comparison of allele frequencies in these two groups showed no significant difference (Supplementary Table 2).

Six families shared strong similarity to the common AJ haplotype (12-4-5-16-4) previously described [20]: one family, PAR-02, showed the entire AJ haplotype while five others (MON-14, PAR-03, MON-09, PAR-16, and MON24) shared two to four contiguous alleles and thus might share a common founder chromosome with AJ patients. Surprisingly, among these families, Jewish ancestries were known only for MON-14. In isolated cases, the entire AJ haplotype was suggested for four individuals (PAR-21, MON-17, the Polish patient MON-18 and LYO-01), and one other shared four of the five alleles (PAR-01). Based on 
allele distribution in the control population (Supplementary Table 2), the calculated frequency of the 12-4-5-16-4 haplotype is $3.9 \times 10^{-4}$, demonstrating the rarity of this particular haplotype.

One other AJ haplotype was reported by Lebre et al. [13] in the previously reported French family PAR-11. This haplotype differs only for the marker D9S2161 (12-4-3$16-4)$, suggesting that a mutation has probably occurred in the microsatellite locus in the common AJ haplotype (124-5-16-4). Among our reconstructed haplotypes, we found that this mutated 12-4-3-16-4 haplotype was potentially shared by three other isolated patients (PAR-06, PAR-07, and PAR-13). Only PAR-13 has known AJ origins. Once more, the observed frequency is statistically higher than expected $\left(4.7 \times 10^{-4}\right)$.

Two families, MON-07 and LIL-01, in the absence of a known family link, share a common haplotype (6-5-3-12$1)$ that is also partly found in family PAR- $08(X-5-3-12-X)$. The calculated frequency of this haplotype is $8 \times 10^{-5}$. Therefore, with an observed frequency of $0.06 \%$, there is a strong association between this haplotype and the mutation.
In our series, no similarity was found with the two previous haplotypes (14-4-2-14-4 and 12-6-4-0-2) found in French Canadian families [12]. This result suggests that either the mutation arose after migration of French to Canada or that these peculiar haplotypes have been lost in the French population. Finally, no other common haplotype could be deduced in the 15 other isolated individuals.

\section{Discussion}

In this paper, we report the first exhaustive nationwide study corresponding to the largest genetically ascertained population of TORIA carriers. Fifty-three index cases were initially recruited allowing subsequent analysis of 32 affected family members and 72 at-risk asymptomatic family members (Fig. 2). Overall, we have identified the mutation in 106 individuals, 23 corresponding to asymptomatic relatives. Two reported affected relatives were in fact phenocopies as they were not found to carry the TORIA mutation (other genes might be implicated).

Table 2 Disease haplotypes at 5 microsatellite loci in the French population

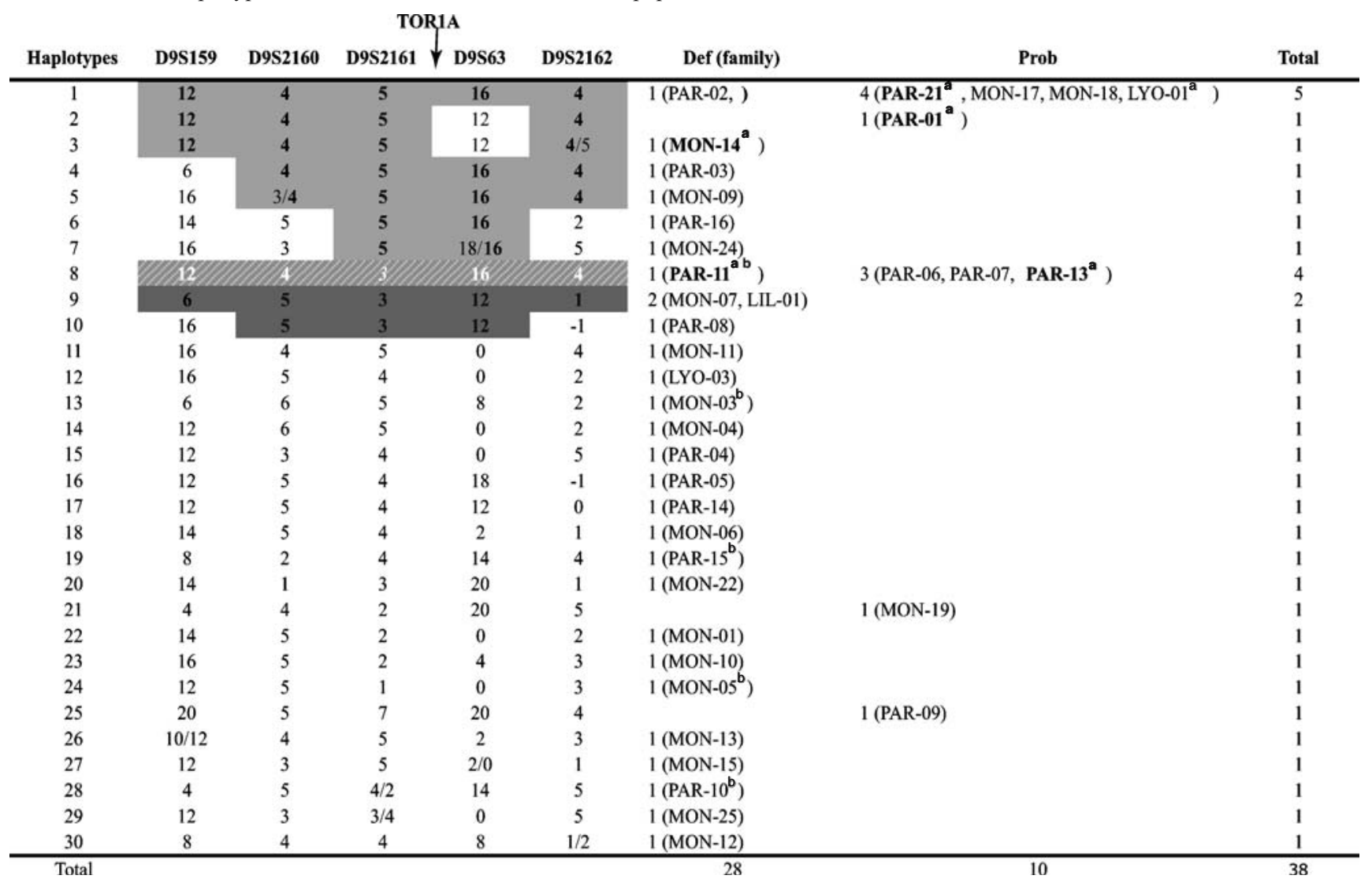

Def Phased disease-bearing chromosomes determined by inheritance, Prob phased disease-bearing chromosomes not determined by inheritance

${ }^{\mathrm{a}}$ Indicated families with Ashkenazi-Jewish origins

${ }^{\mathrm{b}}$ Previously described in Lebre et al. (13) 
Taking into account that (1) EOTD prevalence in Europe is between 0.3 and 0.5:100,000 [19], 2) TOR1A mutations are estimated to account for only $30-60 \%$ of EOTD in nonJews, (3) a population of $61,538,322$ inhabitants in metropolitan France in January 2007, and finally (4) a mutation penetrance of $30 \%$, we would expect a number of symptomatic TORIA mutation carriers ranging from 55 to 184 and a total number of mutation carriers (symptomatic and asymptomatic) from 184 to 613 . Whereas the small number of identified symptomatic carriers $(N=83)$ is in the calculated range, a lower number of asymptomatic carriers $(N=23)$ than expected has been identified. This result can likely be explained by the difficulty to achieve exhaustive inclusion of all asymptomatic relatives of TOR1A mutation carriers in clinical and genetic studies. Moreover, presymptomatic diagnosis is only authorized in adults in France when no direct benefit is expected for the patient. The proportion of symptomatic carriers should not be modified by studying focal forms of the disease in which TOR1A mutation have been rarely found $[13,25,26]$. Even though the penetrance of the c.907delGAG mutation cannot be accurately defined, our results allow the estimation of minimum mutation frequency of $0.17: 100,000$ (106 mutation carriers for $61,538,322$ inhabitants) and a TOR1A-linked dystonia frequency of 0.13:100,000 (83 symptomatic TOR1A mutation carriers for $61,538,322$ inhabitants).

The collection of clinical data in the 83 genetically ascertained patients (Fig. 2) showed a large intra and interfamilial clinical heterogeneity, from paucity of symptoms to extremely severe forms resulting in death. When comparing our data with those previously published for distinct populations like Asian [21-24], AJ, and non-AJ American populations [1], the French characteristics most closely resemble what was reported for the AJ population with a majority of involvement in the limbs, a higher prevalence of site of onset in the arms, and a lower occurrence of onset in trunk, neck, and cranial muscles (Table 1). These results are not due to the unexpectedly high frequency in our series $(20.7 \%, 11 / 53)$ of the particular haplotype reported to be associated with a founder effect in the AJ population, as they were replicated when families with an AJ haplotype were removed. Only four of these families had known Jewish origins. These data confirm that clinical manifestations of the TORIA mutation probably vary according to different ethnicities, suggesting population-specific diseasemodifying factors. The presence of only one recurrent haplotype among the remaining disease chromosomes suggests that the mutation probably occurred independently in the French population even if de novo cases could not be demonstrated in our series [27, 28]. Finally, the identification of only 53 TOR1A families argues for the scarcity of this disease in the French population.

\section{Databases}

OMIM: http://www.ncbi.nlm.nih.gov/entrez/query.fcgi? $\mathrm{db}=$ OMIM.

Acknowledgements We thank all patients and family members for participation in this study. M.Y.F. is supported by a grant from Association Française contre les Myopathies (AFM).This work was supported by the LFCD-AMADYS and INSERM Dystonia National Network and Gis Maladies Rares.

\section{References}

1. Bressman SB, Sabatti C, Raymond D, de Leon D, Klein C, Kramer PL, Brin MF, Fahn S, Breakefield X, Ozelius LJ, Risch NJ (2000) The DYT1 phenotype and guidelines for diagnostic testing. Neurology 54:1746-1752

2. Gambarin M, Valente EM, Liberini P, Barrano G, Bonizzato A, Padovani A, Moretto G, Fiorio M, Dallapiccola B, Smania N, Fiaschi A, Tinazzi M (2006) Atypical phenotypes and clinical variability in a large Italian family with DYT1-primary torsion dystonia. Mov Disord 21:1782-1784

3. Ozelius L, Hewett J, Page C, Bressman S, Kramer P, Shalish C, de Leon D, Brin M, Raymond D, Corey D, Fahn S, Risch N, Buckler A, Gusella J, Breakefield X (1997) The early-onset torsion dystonia gene (DYT1) encodes an ATP-binding protein. Nat Genet 17:40-48

4. Tuffery-Giraud S, Cavalier L, Roubertie A, Guittard C, Carles S, Calvas P, Echenne B, Coubes P, Claustres M (2001) No evidence of allelic heterogeneity in the DYT1 gene of European patients with early onset torsion dystonia. J Med Genet 38:E35

5. Fletcher NA, Harding AE, Marsden CD (1990) A genetic study of idiopathic torsion dystonia in the United Kingdom. Brain 113(Pt 2):379-395

6. Pauls DL, Korczyn AD (1990) Complex segregation analysis of dystonia pedigrees suggests autosomal dominant inheritance. Neurology 40:1107-1110

7. Risch NJ, Bressman SB, Senthil G, Ozelius LJ (2007) Intragenic cis and trans modification of genetic susceptibility in DYT1 torsion dystonia. Am J Hum Genet 80:1188-1193

8. Burke RE, Brin MF, Fahn S, Bressman SB, Moskowitz C (1986) Analysis of the clinical course of non-Jewish, autosomal dominant torsion dystonia. Mov Disord 1:163-178

9. Marsden CD (1988) Investigation of dystonia. Adv Neurol 50: $35-44$

10. Opal P, Tintner R, Jankovic J, Leung J, Breakefield XO, Friedman J, Ozelius L (2002) Intrafamilial phenotypic variability of the DYT1 dystonia: from asymptomatic TOR1A gene carrier status to dystonic storm. Mov Disord 17:339-345

11. Risch N, de Leon D, Ozelius L, Kramer P, Almasy L, Singer B, Fahn S, Breakefield X, Bressman S (1995) Genetic analysis of idiopathic torsion dystonia in Ashkenazi Jews and their recent descent from a small founder population. Nat Genet 9:152-159

12. Kramer P, Heiman G, Gasser T, Ozelius L, de Leon D, Brin M, Burke R, Hewett J, Hunt A, Moskowitz C, Nygaard T, Wilhelmsen K, Fahn S, Breakefield X, Risch N, Bressman S (1994) The DYT1 gene on 9q34 is responsible for most cases of early limb-onset idiopathic torsion dystonia in non-Jews. Am J Hum Genet 55:468-475

13. Lebre AS, Durr A, Jedynak P, Ponsot G, Vidailhet M, Agid Y, Brice A (1999) DYT1 mutation in French families with idiopathic torsion dystonia. Brain 122(Pt 1):41-45 
14. Carmona J, Burguera JA, Molla B, Mulas F, Smeyers P, Carratala F, De Yebenes JG, Hoenicka J, Palau F (2003) Unique origin and low penetrance of the 946delGAG mutation in Valencian DYT1 families. Clin Genet 64:153-159

15. Ikeuchi T, Nomura Y, Segawa M, Ozelius LJ, Shimohata T, Tsuji S (2002) Multiple founder effects in Japanese families with primary torsion dystonia harboring the GAG deletion in the Tor1A (DYT1) gene. Neurogenetics 4:105-106

16. Valente EM, Povey S, Warner TT, Wood NW, Davis MB (1999) Detailed haplotype analysis in Ashkenazi Jewish and non-Jewish British dystonic patients carrying the GAG deletion in the DYT1 gene: evidence for a limited number of founder mutations. Ann Hum Genet 63(Pt 1):1-8

17. Raymond D, Bressman S (2006) Early-onset primary dystonia (DYT1). In, 2006

18. Frederic M, Lucarz E, Monino C, Saquet C, Thorel D, Claustres M, Tuffery-Giraud S, Collod-Beroud G (2007) First determination of the incidence of the unique TOR1A gene mutation, c.907delGAG, in a Mediterranean population. Mov Disord 22:884-888

19. Kamm C (2006) Early onset torsion dystonia (Oppenheim's dystonia). Orphanet J Rare Dis 1:48

20. Ozelius L, Hewett J, Kramer P, Bressman S, Shalish C, de Leon D, Rutter M, Risch N, Brin M, Markova E, Limborska S, Ivanova-Smolenskaya I, McCormick M, Fahn S, Buckler A, Gusella J, Breakefield X (1997) Fine localization of the torsion dystonia gene (DYT1) on human chromosome 9q34: YAC map and linkage disequilibrium. Genome Res 7:483-494

21. Ikeuchi T, Shimohata T, Nakano R, Koide R, Takano H, Tsuji S (1999) A case of primary torsion dystonia in Japan with the 3-bp
(GAG) deletion in the DYT1 gene with a unique clinical presentation. Neurogenetics 2:189-190

22. Im JH, Ahn TB, Kim KB, Ko SB, Jeon BS (2004) DYT1 mutation in Korean primary dystonia patients. Parkinsonism Relat Disord 10:421-423

23. Matsumoto S, Nishimura M, Kaji R, Sakamoto T, Mezaki T, Shimazu H, Murase N, Shibasaki H (2001) DYT1 mutation in Japanese patients with primary torsion dystonia. Neuroreport 12:793-795

24. Nomura Y, Ikeuchi T, Tsuji S, Segawa M (2000) Two phenotypes and anticipation observed in Japanese cases with early onset torsion dystonia (DYT1) - pathophysiological consideration. Brain Dev 1(22 Suppl):S92-101

25. Warner T, Fletcher N, Davis M, Ahmad F, Conway D, Feve A, Rondot P, Marsden C, Harding A (1993) Linkage analysis in British and French families with idiopathic torsion dystonia. Brain 116:739-744

26. Brassat D, Camuzat A, Vidailhet M, Feki I, Jedynak P, Klap P, Agid Y, Durr A, Brice A (2000) Frequency of the DYT1 mutation in primary torsion dystonia without family history. Arch Neurol 57:333-335

27. Hjermind LE, Werdelin LM, Sorensen SA (2002) Inherited and de novo mutations in sporadic cases of DYT1-dystonia. Eur J Hum Genet 10:213-216

28. Klein C, Brin M, de Leon D, Limborska S, Ivanova-Smolenskaya I, Bressman S, Friedman A, Markova E, Risch N, Breakefield X, Ozelius L (1998) De novo mutations (GAG deletion) in the DYT1 gene in two non-Jewish patients with early-onset dystonia. Hum Mol Genet 7:1133-1136 